\title{
Development of PISA Mathematical Problem Model on the Content of Change and Relationship to Measure Students Mathematical Problem-Solving Ability
}

\author{
Siti Aisyah Hasibuan ${ }^{1 *}$, KMS. M. Amin Fauzi ${ }^{1}$, Mukhtar ${ }^{1}$ \\ ${ }^{1}$ Universitas Negeri Medan, INDONESIA \\ *CORRESPONDENCE: $\square$ sitiaisyahhasibuan2@gmail.com
}

\begin{abstract}
This study aims to describe: 1) The validity and reliability of the PISA model mathematical problems on the change and relationship content developed; 2) The practicality of PISA mathematical problem models on the developed change and relationship content; 3) Students' mathematical problem-solving abilities on mathematical problems in the PISA model of content change and relations developed. This research is a Tessmer type development model. This study consists of 2 stages, namely the preliminary stage, and the formative evaluation (prototyping) stage which includes expert reviews, one-to-one, and small groups and the field test (high resistance in revision) stage. The subjects of this study were 32 students of Grade VIII-2 of SMP Negeri 6 Padangsidimpuan. Data collection techniques used were walkthrough, documents, tests, and questionnaires. Based on the results of the study, it was found that the mathematical problems of the PISA model on the content of change and relationship that has been developed produce valid questions that are reliable with high interpretation, as well as practical. PISA mathematical problem tests on the content of change and relationship with the students' mathematical problem-solving ability reached a score of $62.50 \%$ with enough categories.
\end{abstract}

Keywords: PISA, content change and relationship, problem-solving ability

\section{INTRODUCTION}

The PISA (Program for International Student Assessment) is a study of an international student assessment program organized by the Organization for Economic Cooperation and Development (OECD) for economic cooperation and development (OECD, 2013). PISA aims to assess the extent to which students who sit at the end of a basic education year (students aged 15 years) have mastered the knowledge and skills necessary to participate as citizens or community members who are responsible and responsible. The PISA program is very important for measuring students' abilities in mathematics literacy. According to the OECD (2012), mathematical literacy is the ability of individuals to formulate, apply, and interpret mathematics in various contexts, including mathematical reasoning abilities and use mathematical concepts, procedures, facts and mathematical tools to describe, explain and predict phenomena/events.

Wardhani (2011) states that many of the weaknesses of Indonesian students' mathematical abilities are revealed in the results of the PISA study. In general, students' weaknesses are not yet able to develop their reasoning abilities, do not have the habit of reading while thinking and working in order to understand essential and strategic information in solving problems, and still tend to "accept" information and then forget it, so mathematics subjects have not been able to become a "school of thinking" for student. The results of the

Article History: Received 10 October $2019 \bullet$ Revised 23 October $2019 \bullet$ Accepted 23 October 2019

(C) 2020 by the authors; licensee Modestum Ltd., UK. Open Access terms of the Creative Commons Attribution 4.0 International License (http://creativecommons.org/licenses/by/4.0/) apply. The license permits unrestricted use, distribution, and reproduction in any medium, on the condition that users give exact credit to the original author(s) and the source, provide a link to the Creative Commons license, and indicate if they made any changes. 
PISA survey in Indonesia in 2012 ranked 64 out of 65 countries, and experienced an increase in 2015, namely Indonesia at the level of 69 out of 76 countries (OECD, 2018), the results of the PISA survey above show that Indonesian students are always almost ranked last in the world. These results occur in a row during the test. This shows that Indonesian students have low problem-solving skills. This is in line with Baswedan (2011), calculated from score 6, the mathematical abilities of Indonesian students are only on the second level. Edo, Hartono, and Putri (2013) stated that students were only able to answer PISA questions levels 1, 2, and 3, and few students were able to complete levels 4,5 , and 6 .

The PISA question was developed based on 4 content namely; shape and space, change and relationship, quantity, and uncertainty. In this study, researchers limit the content that will be developed to be investigated, namely the question of PISA on change and relationship content. OECD (2013) Change and relationship, Change and relationships are proven in diverse settings such as organism growth, music, season cycles, weather patterns, employment levels, and economic conditions. This category deals with the subject matter of algebra, including algebraic forms, equations and inequality, representations in tables and graphs, which are central in describing, modeling, and interpreting phenomena of change. The main aspects of change and relationship according to Julkardi and Zurnaidi (2017) are displaying changes in a comprehensive form, understanding the types of fundamental changes, recognizing certain types of changes when they occur, applying these techniques to the outside world, and controlling changes in the universe for results best.

The characteristics of PISA questions consist of three components (OECD, 2013), namely:

1. Component content. There are four contents in the PISA problem, change and relationship, space and shape, quantity and uncertainty of data.

2. Process components, consisting of a person's ability to formulate, use, and interpret mathematics in solving problems.

3. Context components. There are four contexts in the PISA problem namely, personal, occupational, social, scientific.

Wardhani (2005) suggests that PISA questions are very demanding of reasoning ability and problemsolving ability. In his study, Pisa tests students by using tests. In the PISA questions, there are eight characteristics of mathematical cognitive abilities, namely, communication, mathematics, representation, reasoning and argumentation visions, strategies for solving problems, using symbolic, formal and technical language and operations, using mathematics tools.

The PISA questions were developed based on the four contents as follows (OECD, 2013):

1. Change and relationships are proven in diverse settings such as organism growth, music, seasonal cycles, weather patterns, employment levels, and economic conditions. This category deals with the subject matter of algebra, including algebraic forms, equations and inequality, representations in tables and graphs, which are central in describing, modeling, and interpreting phenomena of change.

2. Space and Shape include phenomena related to the visual world involving patterns, nature of objects, position and orientation, representation of objects, coding visual information, navigation, and dynamic interactions related to forms that are real. This category deals with geometry lessons. Geometry serves as an important foundation for space and form, but the category goes beyond traditional geometry in content.

3. Quantity is the most challenging and most essential mathematical aspect of life. This category deals with the relations of numbers and patterns of numbers, including the ability to understand the size, number patterns, and everything related to numbers in everyday life, such as counting and measuring certain objects. Included in the content of this quantity is the ability to reason quantitatively, presenting something in numbers, understanding mathematical steps, calculating by rote (mental calculation), and doing an estimation.

4. Uncertainty and data. Uncertainty is a phenomenon that lies at the heart of mathematical analysis (at the heart of mathematical analysis) of various situations. Statistical theories and opportunities are used to solve this phenomenon. The Uncertainty and Data category includes the recognition of the place of variations in a process, the meaning of quantification of these variations, knowledge of uncertainty and error in measurement, and knowledge of chance. Data presentation and interpretation are key concepts in this category.

Based on the results of the 2003 PISA data (Stacey, 2011), the lowest score on PISA math content obtained by Indonesian students was change and relationship content compared to other content. The change and 
relationship score is 334, while space and shape content with a score of 361, content quantity with a score of 357 , and uncertainty and data content with a score of 385. The following are the results obtained by Indonesian students at PISA in 2003 according to the mathematical content provided by PISA:

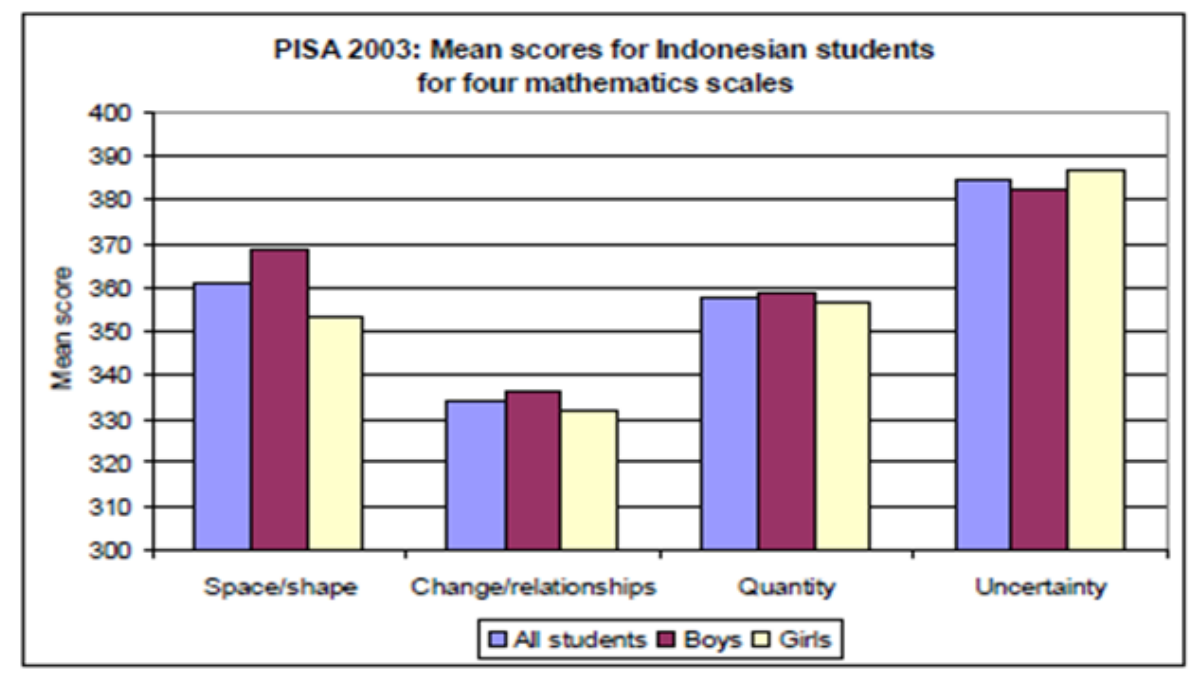

Figure 1. Scores Obtained by Indonesia in Every Mathematics Content at PISA 2003 (Stacey, 2011)

According to Wati (Simalango, Darmawijoyo, \& Aisyah, 2018) revealed factors that cause students to mistake in solving PISA questions about change and relationship content, namely students' reasoning ability and creativity are low in solving problems in real contexts and manipulating in the form of algebra. The PISA model with change and relationship content is very important because the existence of this type of problem can encourage students' interest to be motivated again in solving problems in the problem. With this content, it can be used as a reference for teachers to create or design questions specifically and following the potential of students by using solutions in solving problems in each problem. Skills and learning problem-solving mathematics independence of students can be trained and developed when the teacher can choose approaches, models, methods, or appropriate learning strategies and following the material, situations, and conditions of students in learning (Siregar, Asmin, \& Fauzi, 2018).

The problem is the situation of someone who does not know the algorithm or procedure of the solution, but the person is interested in solving it (Szetela \& Nicol, 1992). In solving problems not all questions are problems. A question will become a problem if only questions that indicate there are challenges that have not been solved by routine student procedures are known (Simanjuntak, et al, 2018). Problems in mathematics are defined as a situation or situation where a person cannot answer questions/problems in the way or habits that apply. According to Mayer (OECD, 2013) problem solving as cognitive processing directed at transforming a given situation into a goal situation when the obvious method of solution is available. The importance of problemsolving is expressed by Beige (Surya, Putri, and Mukhtar, 2017) by stating that through problem-solving, students can learn about deepening their understanding of mathematical concepts by working through selected issues using mathematical applications for real problems. The development of mathematical problemsolving abilities can equip students to think logically, analytically, systematically, critically, and creatively. According to Hasibuan, Saragih, and Amry (2019) that through mathematical problem solving, this allows students to be more analytical in making decisions in their lives. The ability to solve problems is very important in everyday life because we will never be free from problems.

According to Ruseffendi (1991) the goals of problem-solving given to students are: (a) can lead to curiosity and the existence of motivation, foster the nature of creativity; (b) besides having the knowledge and skills (arithmetic, etc.) the ability to read and make correct statements is required; (c) can give rise to original, new, distinctive, and diverse answers, and can add new knowledge or can enhance the application of the knowledge already acquired; (d) inviting students to have problem solving procedures, able to make analysis and synthesis, and are required to make an evaluation of the results of the solution. The problem-solving ability of students can be seen from the stage of problem-solving according to Charles, Lester, and O'Daffer (Szeteladan Nicol, 1992) namely, (1) Understanding the Problem, (2) Solving the Problem, and (3) Answer the Problem. 
Based on the description above, the formulation of the problem in this study are:

1. How is the validity and reliability of the PISA model mathematical problems in the developed change and relationship content?

2. How is the practicality of PISA model mathematical problems in the context of change and relations developed?

3. How are students' mathematical problem-solving abilities in mathematical problems PISA models developed content change and relationship?

\section{METHOD}

The development model used is a formative evaluation Tessmer (Jurnaidi \& Zukardi, 2017). This study consists of 2 stages, namely the preliminary stage, and the formative evaluation (prototyping) stage which includes expert reviews, one-to-one, and small groups as well as the field test (high resistance in revision) stage. The subjects in this study were VIII students of SMP Negeri 6 Padangsidimpuan in the 2018/2019 school year and the object in this study was the mathematical problem of the PISA model on the Change and Relationship content to measure students' problem-solving abilities. In this research what has been developed is a mathematical problem of the PISA model on the content of the Change and Relationship material in the form of algebra, comparison, and social arithmetic by using the characteristics of PISA questions. The object in this study is a mathematical problem of PISA models on the content of Change and Relationship to measure students' problem-solving abilities with algebraic form material, comparison, by using the characteristics of PISA questions.

The development of PISA questions is said to be of quality if it meets three valid, reliable, and practical aspects. A good Problem Item has a good level of validity if the minimum level of validity achieved is in the valid category. If the level of validity is below enough categories, the revision will be based on input from the validator. Revisions were made so that the questions developed were valid.

Table 1. Criteria for validity level

\begin{tabular}{ccc}
\hline No & $\boldsymbol{V a}$ or total mean value of & Validity Criteria \\
\hline 1 & $1 \leq V a<2$ & Invalid \\
\hline 2 & $2 \leq V a<3$ & Less valid \\
\hline 3 & $3 \leq V a<4$ & Sufficiently valid \\
\hline 5 & $4 \leq V a<5$ & Valid \\
\hline
\end{tabular}

Table 2. Validation Result by Experts

\begin{tabular}{ccc}
\hline Question Item & The average value of total validity & Validity Criteria \\
\hline 1 & 4.38 & Valid \\
\hline 2 & 4.18 & Valid \\
\hline 3 & 4.64 & Valid \\
\hline 4 & 4.31 & Valid \\
\hline 6 & 4.46 & Valid \\
\hline
\end{tabular}

Table 3. Levels of Students Mathematical Problem Solving Ability

\begin{tabular}{ccc}
\hline No & Scor Interval & Criteria \\
\hline 1 & $80<k \leq 90$ & Excellent \\
\hline 2 & $65<k \leq 80$ & Good \\
\hline 3 & $55<k \leq 65$ & Sufficient \\
\hline 4 & $0<k \leq 55$ & Less \\
\hline
\end{tabular}

The results are then written in the appropriate column in the table. Furthermore, the Va value or the total average value referred to at the interval to determine the level of validity of the mathematical model of the PISA model, the content of the changes and relationships that have been developed can be seen in Table 2. 


\section{RESULT AND DISCUSSION}

The results of the materials trial activities produce data on validity, reliability, and practicality. Validity data were obtained from three mathematics education lecturers who assessed the PISA mathematical model of the content of change and the relationships developed. The results of the validation of learning materials are shown in Table 2.

\section{Validity and Reliability of the PISA Mathematics Problem Tests Model for Content of Change and Relationship}

The questions that have been tested to students will be analyzed based on the validation of the test, the reliability of the test, the level of difficulty of the test, and the power of differentiation, to produce a valid, reliable and practical question product. Then the results of student answers will be categorized according to indicators of problem-solving, to determine the level of student ability. Following are the results of validation and reliability of students' problem-solving ability tests.

Table 4. Results of Item Validity on the Problem of Mathematical Problem Solving Ability

\begin{tabular}{cccc}
\hline Question Item & $\boldsymbol{r}_{\boldsymbol{x y}}$ & $\boldsymbol{r}_{\text {table }}$ & Interpretation \\
\hline 1 & 0.610 & 0.296 & Valid \\
\hline 2 & 0.816 & 0.296 & Valid \\
\hline 3 & 0.826 & 0.296 & Valid \\
\hline 4 & 0.782 & 0.296 & Valid \\
\hline 5 & 0.699 & 0.296 & Valid \\
\hline 6 & 0.643 & 0.296 & Valid \\
\hline
\end{tabular}

Based on Table 4, 6 valid items were obtained, with the reliability of the problem-solving ability test that is, $\mathrm{r} 11=0.807$ with a very high interpretation of reliability.

The next stage is the implementation of one-to-one trials conducted after the test instrument's mathematical problem-solving ability is validated by experts. One-to-one implementation was tested on three students of class VIII-4 in SMP Negeri 6 Padangsidimpuan with high, medium, and low ability. Subsequently tested on a small group of six students of class VIII-3 at SMP Negeri 6 Padangsidimpuan, two students with high ability, two students with medium ability, and two students with low ability. The questions that have been tested on students aim to find comments or suggestions about the readability of these questions so that researchers can revise the tests. But not all student suggestions can be accepted if the student's suggestion can change the indicators that have been set. After the test is tested the student must fill in the student response questionnaire to the questions that have been developed to see the practicality of the questions. After conducting trials in the one-to-one and small group stages, the next stage is a trial on the subject of research trials, namely students of class VIII-2 at SMP Negeri 6 Padangsidimpuan. Students are asked to work on the PISA math test models of content change and relationship to measure students' mathematical problem-solving abilities by working on as many as 6 items of the test item description.

\section{Practical Mathematics Problem Test PISA Model Content of Change and Relationship}

The student response questionnaire is used to find out the readability of the questions that will be used on the student's mathematical problem-solving test instrument. This response questionnaire was given to three one-to-one trial students, six small group trial students, and 32 field test students. The questionnaire is given to students after the student answers the test instrument questions that have been given. The results of students 'responses to PISA model mathematical problems on change and relationship content to measure students' mathematical problem-solving abilities are in Table 5.

Table 5. Percentage of Student Responses to Pisa Math Models That Have Been Developed

\begin{tabular}{cccc}
\hline No & Trial & Percentage of positive responses & Percentage of negative responses \\
\hline 1 & One-to-one & $68.18 \%$ & $31.82 \%$ \\
\hline 2 & Small group & $72.16 \%$ & $27.84 \%$ \\
\hline 3 & Field Test & $76.42 \%$ & $23.58 \%$ \\
\hline
\end{tabular}

For more details, you can see in the diagram presented in Figure 2. 


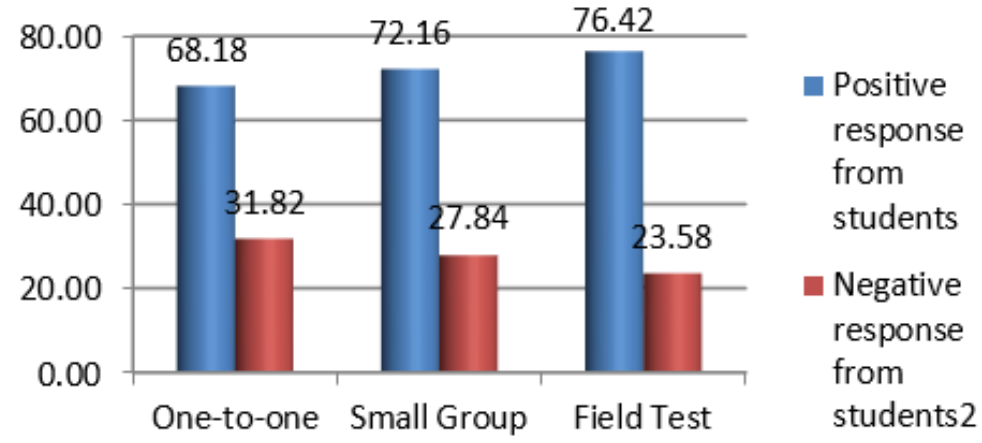

Figure 2. Percentage of Student Responses to Pisa Math Models That Have Been Developed

Based on Figure 2, the average student gives a positive response to the test that has been given to the student. From the students' responses, it can be concluded that the PISA mathematics problem test models of change and relationship content to measure the problem-solving abilities of students that have been developed can be said to be "practical" for use in learning. The test is said to be practical because it has fulfilled the three practical criteria for developing questions namely, criteria: 1) easy to carry out, 2) easy to check, 3) equipped with instructions so that others can be given/initiated.

\section{Students Mathematical Problem-solving Abilities on Mathematical Problem Developed by PISA Content Change and Relationship}

The results of the test trials that have been given to students aim to measure three aspects of problemsolving ability. The three aspects are aspects of understanding the problem, planning the problem, and the third aspect of solving the problem. These three aspects can be seen from the process of student answers presented in Figure 3 .

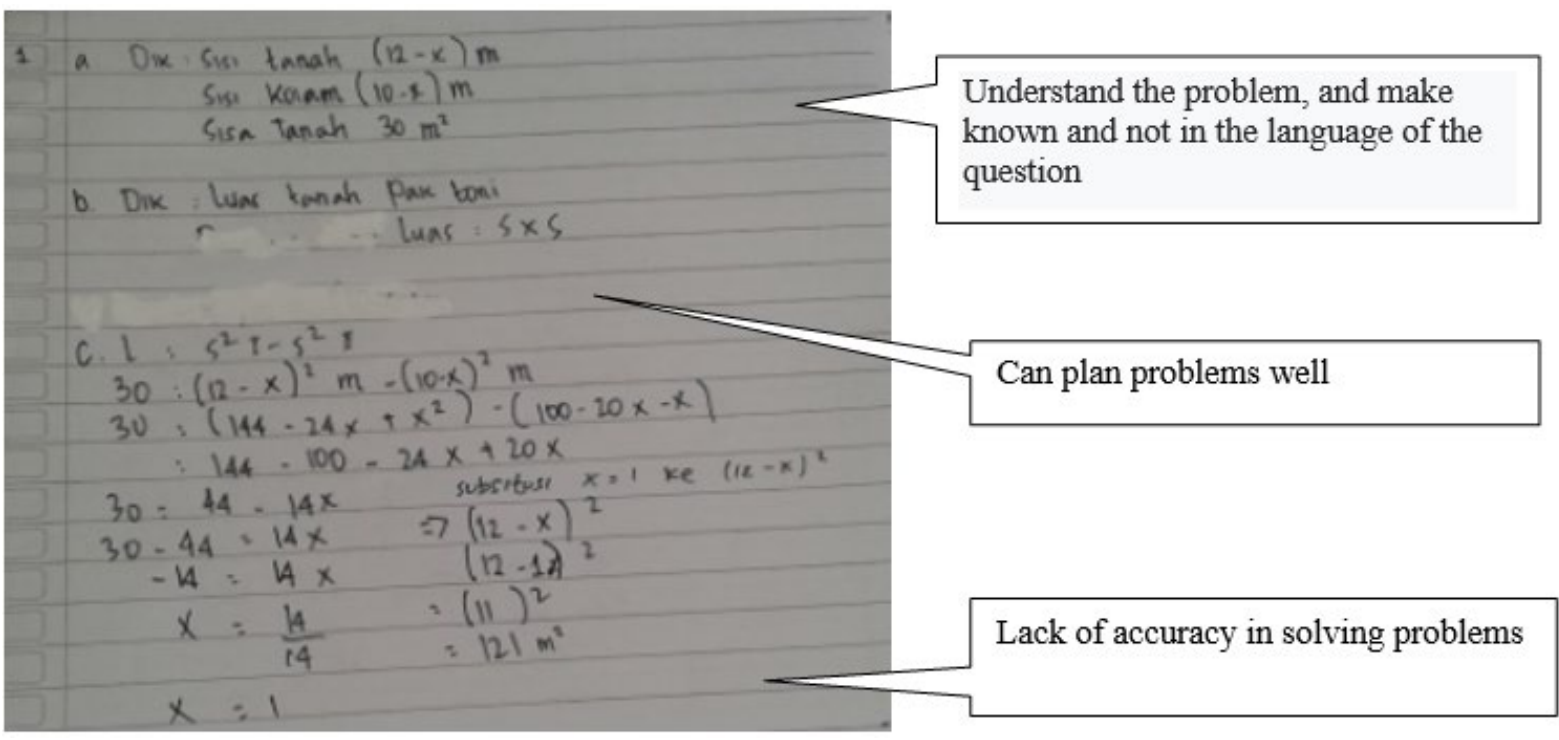

Figure 3. Student answer sheet on question number 2 


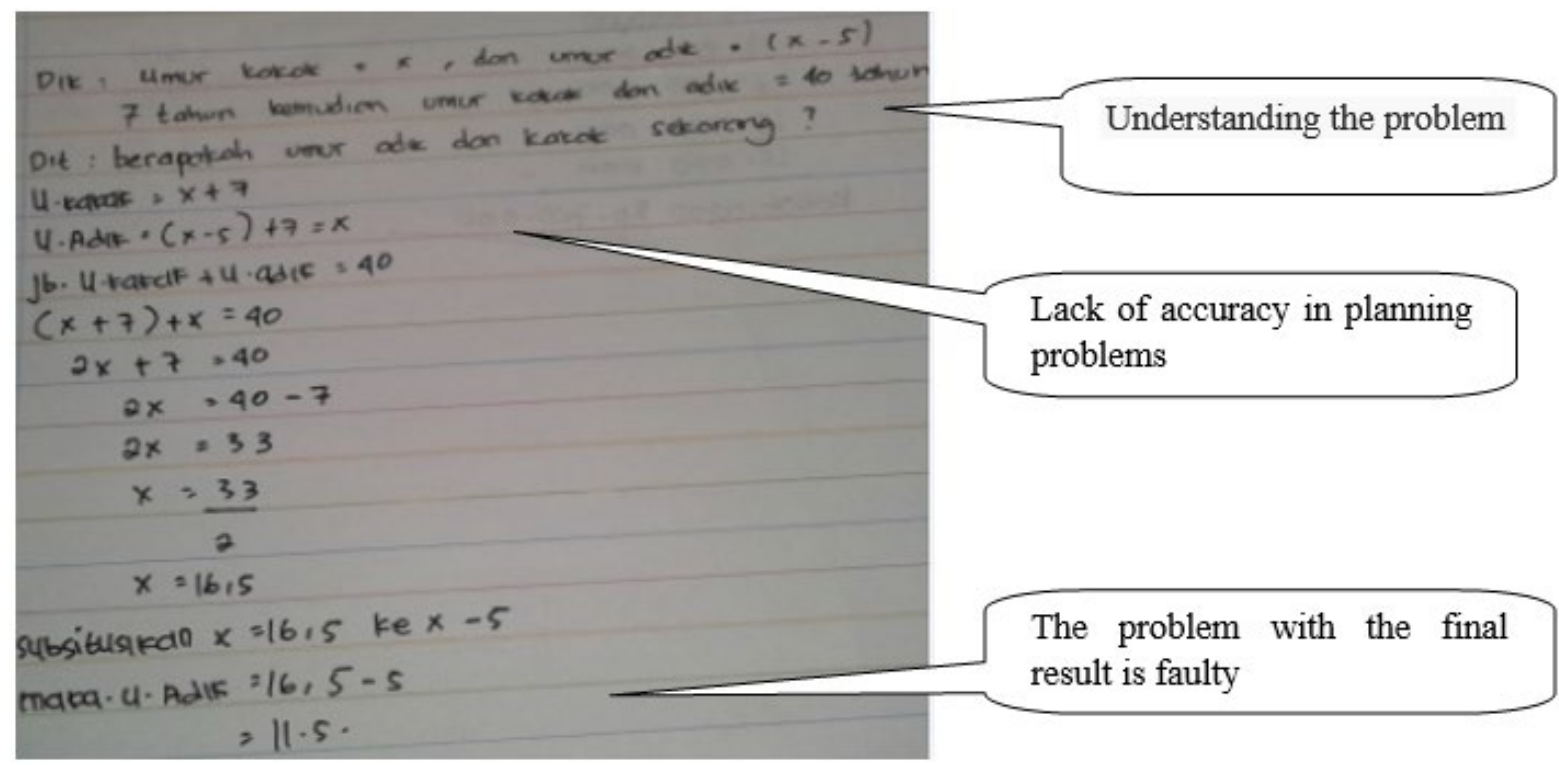

Figure 4. Student answer sheet on question number 6

Based on Figures 3 and 4, it can be seen that students can understand the problem but still use the language of the problem, mistakes in planning the problem solving are in the results of solving the equation, causing the problem to be solved wrongly.

After the PISA mathematics model of content change and related content is developed to measure students' mathematical problem-solving abilities by using tests, the next step is to check the student test results. Table 6 shows the level of students' mathematical problem-solving abilities.

Table 6. Levels of Students Mathematical Problem Solving Ability

\begin{tabular}{ccccc}
\hline No & Score Interval & Total of Student & Percentage & Criteria \\
\hline 1 & $80<k \leq 90$ & 4 & $13 \%$ & Excellent \\
\hline 2 & $65<k \leq 80$ & 10 & $31 \%$ & Good \\
\hline 3 & $55<k \leq 65$ & 12 & $38 \%$ & Sufficient \\
\hline 4 & $0<k \leq 55$ & 6 & $19 \%$ & Less \\
\hline
\end{tabular}

For more details, you can see in the diagram presented in Graph 3.

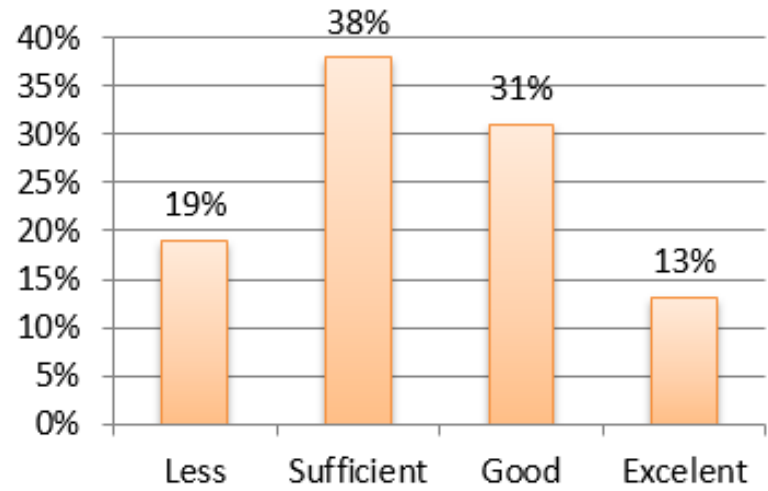

\section{$\square$ Levels of Students Mathematical Problem Solving Ability}

Figure 5. Percentage Levels of Students Mathematical Problem Solving Ability

Based on Table 6 and Figure 5 test instrument data results to measure students 'mathematical problemsolving abilities by using mathematical problems PISA models of content change and relationships that have been developed, the average percentage of students' mathematical problem-solving abilities is $62.50 \%$ with the category "sufficient ". 


\section{CONCLUSION}

Based on the results of research and discussion on the development of PISA mathematical models about the development of problems in changing content and relationships to measure the ability to solve mathematical problems, the results obtained are valid and reliable tests with high interpretation. The ability to solve mathematical problems of students in working on PISA mathematical models on the content of change and relationships is included in the "enough" category with an average percentage of $62.50 \%$

\section{Disclosure statement}

No potential conflict of interest was reported by the authors.

\section{Notes on contributors}

Siti Aisyah Hasibuan - Post Graduate Mathematics Education Program, Universitas Negeri Medan, Medan, Indonesia.

KMS. M. Amin Fauzi - Doctor of Mathematics Education, Master of Education, Lecturer, Mathematics Department Universitas Negeri Medan, Medan, Indonesia.

Mukhtar - Professor of Mathematics, Doctor of Mathematics Education, Master of Education, Lecturer, Mathematics Department, Universitas Negeri Medan, Medan, Indonesia.

\section{REFERENCES}

Baswedan. (2011). Kemampuan Penguasaan Matematika Siswa Indonesia. Tersedia. Retrieved on 6 February 2018 from http://www.tangerangnews.com

Edo, S. I., Ilma, R., \& Hartono, Y. (2014). Investigating Secondary School Students' Difficulties in Modeling Problems PISA Model Level 5 And 6. IndoMS Journal on Mathematics Education (IndoMS - JME), 4(1), 41-58. https://doi.org/10.22342/jme.4.1.561.41-58

Hasibuan, A. M. Saragih, S., \& Amri, Z. (2019). Development of Learning Materials Based on Realistic Mathematics Education to Improve Problem Solving Ability and Student Learning Independence. IEJME, 14(1), 243-252. http://doi.org/10.29333/iejme/4000

Jurnaidi dan Zulkardi. (2017). Pengembangan Soal Model PISA Pada Konten Change and Relationship Untuk Mengetahui Kemampuan Penalaran Matematis Siswa Sekolah Menengah Pertama. Jurnal Pendidikan Matematika, 7(2), 37-54. https://doi.org/10.20527/edumat.v2i1.582

OECD. (2012). PISA 2012 Results in Focus. What 15-Year-Olds Know and What They Can Do with What They Know.

OECD. (2013). PISA 2012 Assessment and Analytical Framework: Mathematics, Reading, Science, Problem Solving and Financial Literacy. Paris: OECD Publishing. https://doi.org/10.1787/9789264190511-en

OECD. (2018). PISA 2015 PISA Results in Focus.

Ruseffendi. (1991). Pengantar Kepada Guru Mengembangkan Kompetensinya Dalam Mengajar Matematika Untuk Meningkatkan CBSA. Bandung: Tarsito.

Simalango, M., Darmawijoyo, \& Aisyah. N. (2018). Kesulitan Siswa Dalam Menyelesaikan Soal-Soal PISA Pada Konten Change and Relationship. Level 4, 5, dan 6 di SMP N 1 Indralaya. Jurnal Pendidikan Matematika, 12(1), 43-58.

Simanjuntak, D., Napitupulu, E. E., \& Manullang, M. (2018). The Enhancement Difference of Student Mathematical Problem Solving Ability between Guided Discovery Learning Model and Direct Learning Model. American Journal of Educational Research, 6(12), 1688-1692. https://doi.org/10.12691/education-6-12-15

Siregar, N., Asmin, \& Fauzi, M. A. (2018). The Effect of Problem Based Learning Model on Problem Solving Ability Student. 3rd AISTEEL, 200, 464-467. https://doi.org/10.2991/aisteel-18.2018.100

Stacey, K. (2011). The PISA view of Mathematical literacy in Indonesia. IndoMS Journal of Mathematics Education, 2(2), 95-126. https://doi.org/10.22342/jme.2.2.746.95-126 
Surya, E., Putri, F. A., \& Mukhtar. (2017). Improving mathematical problem-solving ability and Selfconfidence of high school students through the Contextual learning model. Journal on Mathematics Education, 8(1), 85-94. https://doi.org/10.22342/jme.8.1.3324.85-94

Szetela, W., \& Nicol, W. (1992). Evaluating Problem Solving In Mathematics. New York: Cambridge University Press

Wardhani, S. (2011). Instrument Penilaian Hasil Belajar Matematika SMP: Belajar Dari PISA dan TIMSS, Dirjen Peningkatan Mutu Pendidik dan Tenaga Kependidikan, P4TK, Jogyakarta. 